\title{
Wage Differentials and Industrial Disputes in Nigerian Hospitals
}

\author{
Agba, A. M. Ogaboh (PhD) ${ }^{1,}$ Ushie, E. M. $(\mathrm{PhD})^{2}$ \\ ${ }^{1 \& 2}$ Lecturers, Department of Sociology, University of Calabar, Calabar, Nigeria.
}

\begin{abstract}
The study examined medical and Para-medical staff perception of the impact of wage differential on industrial disputes in Nigerian hospitals. A sample of 1109 respondents were purposively selected from Primary, Secondary and Tertiary hospitals in South-South Geo-political Zone of Nigeria (SSGZN). Information was elicited from respondents via structured questionnaire. Elicited data was analyzed using Pearson product moment correlation coefficient $(r)$ and multiple regression analysis. Results indicated that wage differentials in terms of basic salary, hazard and fringe benefit allowance significantly influenced industrial disputes in Nigerian hospitals. The study further revealed that socio-demographic predictors such as sex, age, category of staff, educational qualification and rank could also influence the incidence of industrial disputes in Nigerian hospitals. We recommended among others policy reform options and the upward review of medical and paramedical staff wages in Nigeria.
\end{abstract}

Keywords: Wage differentials, industrial disputes, wage determination and wage discrimination.

Accepted Date: 28 Nov 2012

\section{Introduction}

The gulf between the rich and the poor is getting wider every day in Nigeria because of wage discrimination. The worker is perpetually conditioned in wage situation that is only enough to multiply his/her race. While political office holders continue to line their pockets with fat wages, that are generated from the sweat of the worker, the average Nigerian worker can hardly feed his/her family. According to Cheeka (2009) a sizeable proportion of Nigerian workers received starvation wage, and over 75 per cent of them live in abject poverty. Hundreds of thousands of working class live in rotten tenements and cannot access or afford medical services. It is increasingly difficult for workers to send their children to school. The new height of poverty among workers in Nigeria could be responsible for the waves of industrial disputes in recent times.

Plethora of studies in Nigeria revealed that those who are privilege to be employed are finding it increasing difficult to survive on their monthly wages. Their take home pay cannot take them home. In the face of increasing inflation of about 14 percent, the Nigerian worker is one of the least paid in the world (ASUUNEC, 2005, Agba, 2007; NLC 2009). The precarious situation of workers is even more worrisome as they have to support relatives and dependents that are unemployed. As the proportion of the unemployed increases in the face of disproportional increase in wages the hope of workers surviving with their relatives/dependents dwindles. Wage situation and the strife to survive among employees especially in the public sector are particularly worse off; being a civil servant today, means signing bond with poverty. The fear of retiring at the instance of low income and facing uncertainty in a society with poor social security system, escalate and intensified all forms of agitation and corrupt practices even among law enforcement agents (Agba, Ikoh, Ushie \& Agba, 2008).

Wage induced industrials disputes in Nigeria is alarming. The proportion and frequency of these disputes are unprecedented (Agba, Ushie \& Agba, 2009). These incessant industrial crises are not without consequences, the irregular school system, declined in economic growth and development in Nigeria is often associated with strikes (Agba \& Agba, 2008). Other consequences include diversion of attention or efforts among workers, ill-relationship between employees and management, man-day lost, decrease in productivity and health costs (Oshimole, 2009; Agba \& Ushie, 2010). While these facts are crystal clear there are little or near absent of empirical research on the effect of wage discrimination on industrial disputes especially in the health sector in Nigeria. The concern of this paper therefore is to investigate factors responsible for wage differential and the effect of salary inequality on industrial disputes in Nigerian hospitals.

\section{Wages and Wage Determination}

\section{Literature Review and Theoretical Consideration}

Wages are often defined as returns to labour. They are payments at regular, weekly, monthly or other intervals plus allowances such as those for working overtime, leave bonuses, adhoc bonuses and other similar payments paid to employees by employers as specified in employment contract (Wikipedia, 2011 ${ }^{\mathrm{a}}$ ). It is the 
direct payments received for work done in a particular establishment. Wages could also be seen from the employees' perspective as all costs incurred for the recruitment and use of employees in a given establishment. It includes among others - direct wages, fringe benefits, social security benefits and cost incurred for human resource training and development.

Wages are means for an acceptable quality of life in a given country. In this regards, wages are classified into three groups - subsistence wage, living wage and fair wage (Navamukundan, 2011). Subsistence wages are remuneration that provides for the subsistence needs of the worker. Living wage are payments that provides for subsistence and means for a quality of life which is socially acceptable in a given society, while fair wage is remuneration which is reached through negotiations based on factors such as opportunity cost of labour, labour market conditions and the general cost of living. Fair wage is between living wage and subsistence wage.

Wages may also be regarded as fixed regular remuneration paid to an employee on daily or weekly basis especially to a manual or unskilled worker (Wikipedia, 2011 ${ }^{\mathrm{a}}$ ). It is monetary remuneration computed on hourly, weekly, or piece work basis, paid to a worker by the employer. Fixing of wage is a controversial subject especially it involves determining minimum wage (Neumark \& Wascher, 2006). In Nigeria, minimum wage has been an issue that is politically contentious and which have generated face -offs between organized labour unions (Nigeria Labour Union) and the federal and state governments. Increase in minimum wage often results to retrenchment of staff and escalations industrial crisis in Nigeria. However, Hutt (1954) argued that collective bargaining helps in cushioning conflict that arises from wage determination. He observes that in an industrial relation system, there are some portions of workers normal remuneration or wages which in the absence of collective bargaining can be transferred to other factors of production at the detriment of the employee.

Wage determination here entails fixing wage rates and fringe benefits rates for each category of workers which the administrator of wage has determined to be prevailing in a given area for a particular type of job. It includes "not only the original decision but any subsequent decisions modifying, superseding, correcting or otherwise changing the rates and scope of the original decision" (US Department of Labour, 2011: 2). It involves factors that influence wage and fringe benefits rates in a defined occupation/profession in a given locality.

There are a number of factors responsible for the wide gulf in pay and earnings rates in Nigeria. The inequality that exist and persists between occupations can be explained by vital determinants. Wage differentials could be determine by the risk a worker takes in performing his/her duties. High pay could be given as compensation for risk-taking by a worker. The gap between the highly and the poorly skilled could constitute a factor for wage differentials; this is because demand for skilled labour grows faster than semi-skilled labour and may result to upward review of pay for the skilled labour. In a competitive labour market the price of labour (wage) is determined by the interaction between supply and demand for labour. As depicted in figure 1, the higher the demand for labour, the higher the price for labour (wage). As demand for labour moves from $\mathrm{D}_{1}$ to $D_{2}$, wage also decreases and as the demand line moves from $D_{1}$ to $D_{3}$ price for labor (wage) increases automatically.

Figure 1: Wage determination in competitive labour market.

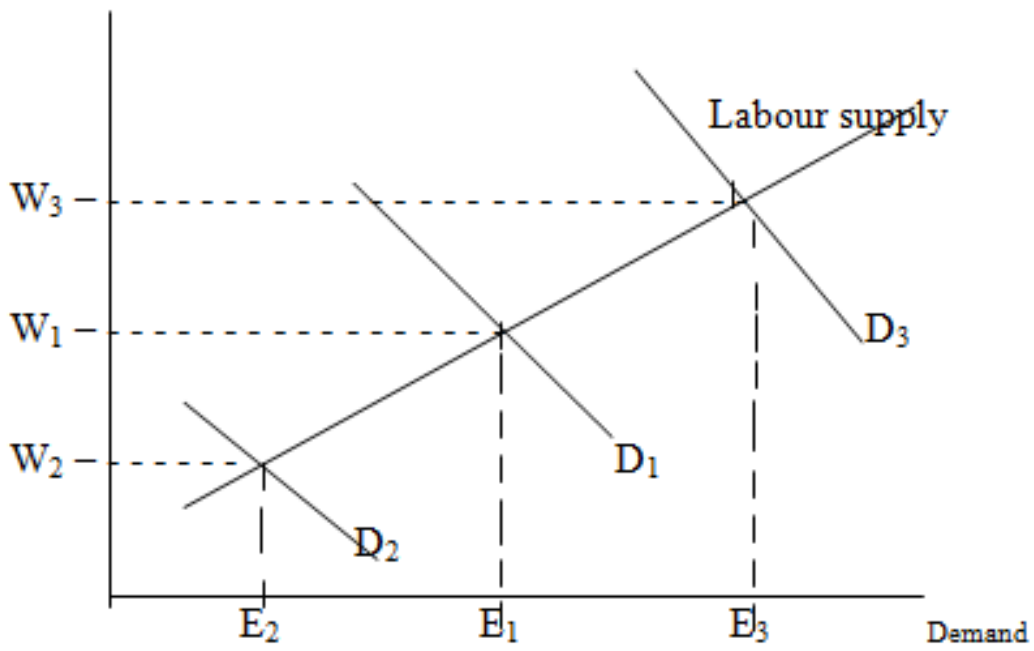

Trade unions could influence wage differentials through collective bargaining. Unions with skill union leaders can effectively bargain for upward review of wages or a make-up salary for their member as against non-union members (Killy, 1967). The cost of human capital development could also serve as important factor in wage inequality. An employer in a competitive labour market may decide to compensate a worker (or 
workers) for the cost or time spent in the course of study or developing skills for the job. Efficiency of workers could also be responsible for wage differentials. A worker with highest productivity could be rewarded with high wage above others with low output (Tutor2u, 2011).

Knights and Sabot (1990) argued that education is the most important determinant of wage differentials. That is, the average differences in levels of schooling significantly influenced differentials in earnings among workers. Kabubo-Mariara (2003) observed that job tenure and years of working experiences could explain for the wide gulf of wage gap amongst workers in the labour market. Lack of experience is therefore plausible explanation for wage gaps in society. According to Owoye (2011), wage policies of government and union density also have significant influence on wage differentials.

\section{Wage Inequality and Discrimination in Nigeria}

The disparity in wages between political office holders and the Nigerian worker is worrisome, and this situation is further aggravated by the frequent increase in politician's compensation packages. According to Nigeria Labour Congress (NLC) (2009), between 2006 and 2007, workers' salaries increased by less than 40 per cent while those of political office holders increased by over 800 per cent. For instance, the salary of Special Assistants to the President that is, Chief Speech Writer to the President and Chief Press Secretary to the President increased from $\mathbf{N} 626,700$ to $\mathbf{N} 4,392,012$. The salary of the President Commander-in-Chief of the Armed Forces of Nigeria increased from N2,506,000 to N24,954,405. See Table 1 for details.

Table 1. Salaries of political office holders (pre and post-consolidation)

\begin{tabular}{|c|c|c|c|}
\hline $\mathrm{S} / \mathrm{N}$ & CATEGORIES & HASS(BASIC) & CONSS* \\
\hline 1 & $\begin{array}{l}\text { Special Assistant to the President: Chief Speech Writer to the } \\
\text { President; Chief Press Secretary to the President }\end{array}$ & 626,700 & $4,392,012$ \\
\hline 2 & $\begin{array}{l}\text { Members, House of Representatives; Deputy Chief of Staff; } \\
\text { Senior Special Assistant }\end{array}$ & 865,200 & $13.102,402$ \\
\hline 3 & $\begin{array}{l}\text { Ministers of State, Senators; Principal Officers of the House of } \\
\text { Representatives; Special Advisers }\end{array}$ & $1,015,700$ & $13,374,240$ \\
\hline 4 & $\begin{array}{l}\text { Deputy Speaker, House of Representatives, Ministers, } \\
\text { Secretary to the Government of the Federation, Head of Civil } \\
\text { Service of the Federation, National Security Adviser; Chief } \\
\text { Economic Adviser; Inspector General of Police, Chairman } \\
\text { Federal Civil Service Commission, Federal Character } \\
\text { Commission, National Salaries, Incomes and Wage } \\
\text { Commission. }\end{array}$ & $1,194,600$ & $15,094,426$ \\
\hline 5 & $\begin{array}{l}\text { Deputy President of Senate; Justice of the Supreme Court, } \\
\text { President, Court of Appeal }\end{array}$ & $1,403,700$ & $15,240,500$ \\
\hline 6 & Speaker of the House of Representatives & $1,649,400$ & $16,348,926$ \\
\hline 7 & $\begin{array}{l}\text { Vice-president of the Federal Republic of Nigeria; President of } \\
\text { the Senate; Chief Justice of Nigeria }\end{array}$ & $1,938,000$ & $21,524,164$ \\
\hline 8 & $\begin{array}{l}\text { President, Commander-in-Chief of the Armed Forces of } \\
\text { Nigeria }\end{array}$ & $2,506,000$ & $24,954,405$ \\
\hline Source & \multicolumn{3}{|c|}{$\begin{array}{l}\text { Adopted from NLC (2009); National Salaries, Incomes and Wages Commission and Revenue } \\
\text { Mobilization Allocation and Fiscal Commission, Abuja. } \\
\text { The Nigerian worker is one of the least paid in sub-Saharan Africa (SSA). Despite the huge revenue } \\
\text { to government from crude oil, the Nigerian worker earns as average of } 550 \text { dollars per annum, only } \\
\text { ountries like Madagascar, Democratic Republic of Congo (DRC), and Malawi. The minimum wage of } \\
\text { ter in Botswana is five times more than that of a Nigerian worker. See figure 2. }\end{array}$} \\
\hline
\end{tabular}




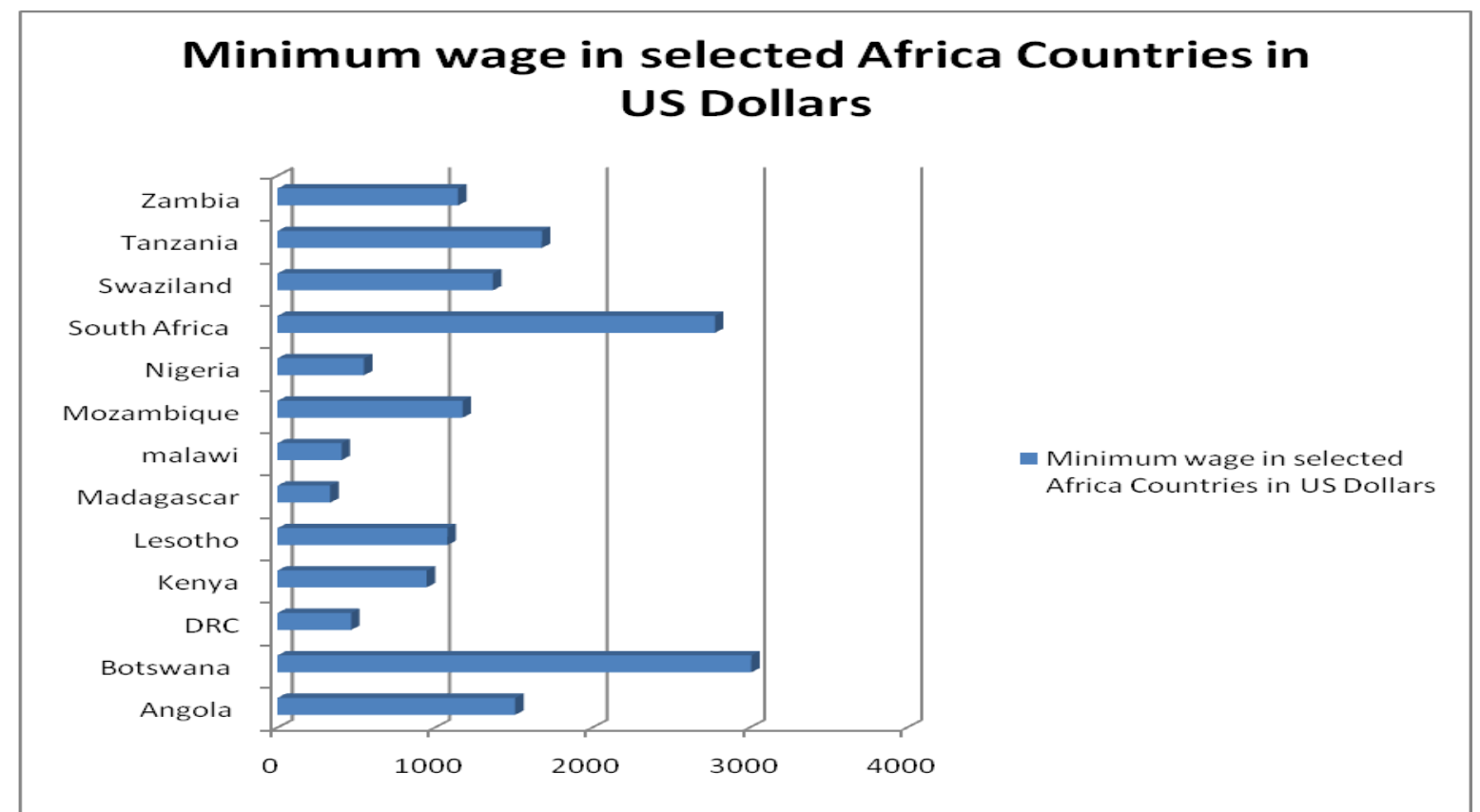

Source: Adopted from NLC (2009:4)

As the cost of living index rises in Nigeria, the real value of the minimum wage of workers dwindles. The quest by workers for a realistic living wage is often resisted by the ruling class, claiming that it would cause inflation and endanger the economy. While workers continue to live with starvation wage; political office holders continue to swell their pockets and line their bank accounts with tax payer's money. For instance it was speculated in 2010 that, it cost the tax payer 290 million Naira to maintain each member of the National Assembly. This implies that a working day earning of a senator is more than the yearly income of a medical doctor and the salary of 48 professors; it is also 3,200 times the yearly income of a level one officer in the Nigerian civil service.

\section{The Concept of Industrial Conflict and the Phenomenon of Industrial Crisis in Nigeria}

Employer-workers conflicts are endemic in industrial society (Ratnam, 2007). This is because "modern industrialization has not been an unmixed blessing; it created a yawing gulf between workers and management" on who should control means of product, proceeds and muscle power and authority at work floor and work community (Mamoria, Mamoria \& Gankar, 2009). Industrial conflict may create discomfort and impede goals, but yet it is part of organizational life (Beck, 1999). Industrial conflict exists when incompatibility of activities occurs between the employer and employees (Deutsel, 1973). It involves a breakdown of mechanisms of decision-making so that workers experience difficulty in selecting an alternative (March \& Simon, 1993). It occurs when parties disagree about the distribution of resources and act because of perceived divergence of interest (Bassey, 2002; Ugal, 2008). It includes organizational activities that obstruct goal attainment or interferes with the effectiveness of workers (Tjosvold, 1986). It spanned from simple differences or disagreement to contention and war between workers and employees (Philips, 1988). Conflicts are inbuilt in the very structure of formal organizations. The departmentalization of organizations and competition for limited resources may give some potential for conflict (Rollinson \& Dundon, 2007). Divergence perception among workers about the rules and regulations of a given organization may also breed industrial conflicts (Ushie \& Iyam, 2004).

Industrials conflict may take the form of a vicious circle and could take conflicting people farther and farther (Dipboye, Smith \& Howell, 1994). And this could spread out of control and lead to undesirable consequences. It could also lead to innovation and learning of new mechanism for resolving industrial disputes (Dublin, 1992). Industrial disputes can take the form of strikes, work-to-rule, overtime ban, lock-out and intimidation (Fashoyin, 1999). Industrial conflict may occur as a result of job insecurity, poor working condition, remuneration and communication (Fashoyin, 1999, Ratnam, 2007).

Divergence views abound on the causes of industrial crisis; while some emphasized on internal factors others laid emphasis on external factors (Blunt \& Jones, 1992). However, some scholars like Fashoyin (1999) and Otobo (2000) held that, the causes of industrial conflicts are multiple, comprising of internal and external factors. This implies that, the analysis of industrial disputes requires a multi-dimensional approach. However in Nigeria, the conventional measure often used in analyzing the incidence of strikes are: frequency, proportion of 
workers involved and duration of the strikes. This is because, large number of disputes occur without resorting to strike even though they are disruptive as strike.

External environment could obstruct industrial peace. According to Otobo (1982; 2000) and Agba (2007), environmental factors such as economy, culture, legislature, social, political and technological change affects the attitude of actors in industrial relation system and may in-turn influence labour-management relations. It also affects leadership style and the implementation of organizational policies. For Instance Fashoyin (1999) posit that the economy boom of the 1970s brought unprecedented growth in Nigeria's foreign exchange earnings, the increase in oil revenue remarkably influenced wage policies in the country and workers took advantage of the economic prosperity to press on government for better wages. Other factors that may influence industrial dispute in Nigeria include non-implementation of union-management agreements and frequent interference in the internal administration of some establishments.

Dispute and strike activities record in Nigeria are far from satisfactory, because of the method of compilation. For instance, Federal Ministry of Labour and Productivity, only record stoppages due to strikes where ten or more workers are involved, or when three working days are lost. Although it is legally binding upon employers to report industrial crisis to the Ministry of Labour and Productivity, many employers, hardly comply with this directives. Consequently, a number of disputes or strikes especially at enterprise level, which is usually of shorter duration, are not reported in official statistics. Despite the limitations in the official records, studies show that between 1964 and1965 the number of strikes occasioned by economic and political factors were low. This figure sky rocketed between 1967 and 1970 compelling the then Military Government to promulgate anti-strike degree. Similarly, 1974 to 1979, recorded a phenomenal increase in the number of disputes and strikes, with its apex in 1979 reflecting the behaviour of workers during the oil boom years. It was obvious from these strikes and disputes, that both workers and employers took vantage of the economic prosperity of the period. Workers had alternative job opportunities and could strike to improve their conditions of employment (Fashoyin, 1999).

Studies also revealed that most strikes in Nigeria are generally of short duration. For instance, between 1966 and 1986, the average duration of strike per worker ranged from 2.4 to 6.0 days. According to Fashoyin (1999:87) the general explanation for the short duration of strikes is "because public policy discourages the payment of salaries during strikes"; and "unions do not have strike funds from which to compensate their striking members". Another explanation for short strikes relates primarily to the structure of unions and collective bargaining. Some strikes are initiated and executed by union leaders at the branch level, and when these strikes are not approved by top union hierarchy, such strikes are called off as soon as possible. Between 1992 and 1996, there were a total of 866 trade disputes nationwide leading to 539 work stoppages involving $5,448,905$ workers with a total of $642,428,679$ man-days lost (Fashoyin, 1999). According to Imhabekhai (2001), these disputes were highly injurious to organizations involved and the general economy. Fashoyin (1999) observe that Sectorial strikes shows that agriculture, hunting, forestry, and fishing witness 81 work stoppages between 1976 to 1989 while mining and quarrying -72; manufacturing - 486; electricity, gas and water - 50; construction - 331; wholesale and retail trade, restaurant and hotel - 101; transportation, storage and communication - 139; financing, insurance, real estate and business services - 144; community, socialincluding hospitals and personal services -298 . While activities not adequately defined accounted for 168 work stoppage within the same period. Fashoyin (1999) further observed that agriculture, hunting, forestry and fishing alone, accounted for 406, 436 man-days lost between 1976 and 1989; mining and quarrying accounted for 130,090 man-days lost within the same period. Community, social-including hospitals and personal services accounted for the highest number of man-days lost between 1976 and 1989; while the least man-days loss of 69,564 occurred in wholesale and retail trade.

\section{Wage Struggle and Industrial Disputes}

The struggle for living wage in Nigeria dates back to the formation of labour union especially in the civil service. Although the slow pace of unionization in the private sector posed some challenges to the quest for living wage, the power of unions in persuading employers for up-ward review of salaries/wages was still very significant. The first recorded wage induced strike in Nigeria was in 1945 when workers staged 45 days strike for a cost of living allowance. In 2007 and 2010 industrial actions by Nigeria Labour Congress (NLC) were undertaken to press government for up-ward review of workers' wages. Between 1945 and 2007, workers including medical and para-medical staff have through NLC struggle 15 times for wage improvement and for a favourable national minimum wage legislature. Surprisingly, were agreements are reached with government; they are often distorted at implementation level. For instance, the 2000 Wage Review Agreement provided for 25 per cent wage increase with effect from May 1, 2001 and 15 per cent wage increase in May 1, 2002, government never implemented this agreement; this act was responsible for most of the strikes in the country (NLC, 2009). 
In tertiary institutions wage induced industrial disputes are endemic. Inventory of wage disputes in Nigeria Universities includes the 1993 and 1994, Academic Staff Union of Universities (ASUU) strikes that lasted for four and six months respectively (Imhabekhai, 2001). In 1996 another strike by ASUU was occasioned by government refusal to review the wages and work condition in Universities. Between 1997 and 2008, there were also a number of strikes, and other industrial actions such as work-to-rule actions by ASUU to compel government to rethink in the upward review of the wages of academic staff in Nigerian Universities.

\section{Theoretical Consideration}

This study adopted four theories, viz: (1) Erica Goshen (1991) Wage Differentials Theory (WDT), (2) Subsistence Theory of Wages/Iron or Brazen Law of Wages, (3) J. Kelly (1998) Social Mobilization Theory (SMT), and (4) Residual Claimant Theory (RCT).

Erica Goshen (1991) Wage Differential Theory (WDT) proposed reasons for wages variation among workers, these factors include labour quality, compensation differentials, cost of information, efficiency wage, bargaining power of workers/unions and employer sharing profit with employees. Goshen (1991) posits that the systematic sorting of workers by their ability is significant for the establishment of wage differentials. That workers level of education, their productive capacities and the quality of their input and output determined wage variation. Employer's ability or policy to pay compensation to employee for working under adverse conditions or environment could also influence workers' wages. Another explanation for wage variation suggests that the cost of employees accessing vital information for juicy employment elsewhere plays significantly role in wage differentials.

WDT posit that employers' decision to use salary/wage as a stimuli or motivation for efficiency could account for wage differentials. This involves the employer paying employees more than the market-clearing wage in order to motivate them to increase productivity. Goshen (1991), further posits that workers bargaining power through their various unions could also determine wage and significantly influence wage differentials among colleagues. Goshen added that employers' willingness to share profits with employees could also be responsible for wage differentials.

Subsistence Theory of Wages/Iron or Brazen Law of Wages owes its origin to Physiocratic School of France. The theory posits that wages in a long run should be equal to the minimum level of subsistence in a given society; this implies that wages should be the amount which is just sufficient to meet the basic necessities of life of the employee and his family in a given society. The theory argues that if wages exceed subsistence level, the worker will be exposed to extravagant life. The worker will marry early and will produce more children and this will lead to the production of excess workers more than what employees required. Consequently, the supply of labour will exceed demand leading to a downward slope in workers' wages, which may not be sufficient to maintain employees' families. When this happens, agitation for wages is unavoidable and industrial conflict is eminent. The theory is criticized for its wrong preposition that when money income increases beyond subsistence level, workers will marry early and produce more children. On the contrary, high profile people/workers have few numbers of children (http:/www.economiesconcepts 2011).

Social Mobilization Theory (SMT) recognizes that industrial conflict could occur when workers believe that they are paid below the going rate in comparison to a similar workgroup elsewhere. Kelly (1998) argued that what workers judge as dissatisfaction must be guided by sense of justice for it to be legitimate for industrial action. For instance if management proposes restructuring a firm because of its financial state, such decision is unavoidable, workers should judge right before embarking on an industrial action. Kelly's theory is therefore relevant to this study because it help the researchers to understand the impact of wage differential on industrial dispute and the process for underpinning conflict among workgroups.

Residual Claimant Theory (RCT) is another wage determined theory. The theory was introduced by American Economist Walker and later developed by Jevon. Residual Claimant Theory posits that employees' wages in a given establishment or society is equal to the whole production minus rent, taxes and the interest on capital. This implies that workers remuneration is remains after payment of rent, interest, profit and taxes out of the national dividend. The implication is that any demand by labour that exceeds the "remains" will lead to "employer's deficiency" or "inability to pay". It suggests that industrial dispute(s) may occur if workers demand or insist on wages that is beyond the "remains". However, the theory failed to explain the influence of labour unions in pay rise of workers. The theory also ignores the influence of supply and demand for labour as a determinant of wage (http://www.economiesconcept.com 2011).

\section{Study Area}

The data reported here were obtained from a field survey on medical and para-medical staff perception of wage differentials and industrial disputes in Nigerian hospitals. The survey was carried out in the SouthSouth Geo-political Zone of Nigeria (SSGZN). The study covers primary, secondary and tertiary hospitals in the region. The SSGZN comprised of six states including Akwa Ibom, Bayelsa, Cross River, Delta, Edo and Rivers 
State (Agba, Ikoh, Ushie \& Bassey, 2010). Out of 140,003,542 million people in Nigeria, over 21,014,655 million resides in the SSGZN (National Bureau of Statistics, 2006; National Population Census, 2006). The geopolitical configuration of the region comprised of 18 senatorial districts, three from each state; and 123 local government areas and; these divisions allows for ease of administration (Agba, Ikoh, Ushie \& Bassey, 2010).

Data was elicited from 1109 medical and paramedical staff from the region through structured questionnaire. The instrument is made up of two sections. The first considered the socio-demographic data of respondents including age, sex, category of staff, rank, marital status and educational qualification. The second section elicited data on basic salary, fringe benefits allowance, hazard allowance and industrial disputes.

Apart from state capitals in the region, were tertiary hospitals are established, primary health care centres and general hospitals are dominant in rural areas. The primary health care centres are control by the local government area councils with support from state and federal governments. The general (secondary hospitals) and tertiary hospitals are under the ownership and controlled of states and federal government respectively. These hospitals in one time or the other have experienced industrial disputes that paralyzed their operation in the geo-political zone; this made their choices for this study imperative.

The SSPZ is the economic nerves of Nigeria, contributing about 90 percent of the country's foreign earning. Paradoxically poverty in the region is high. There is also high incidence of epidemic outbreak, poor nutrition and sanitation, high mortality and mobility rate. These problems are further aggravated by continuous environmental pollution occasioned by oil exploration.

\section{Methodology}

This study adopts survey design. It was adopted because it allows data to be collected from a sample to discover the relative incidence and interactions among sociological and psychological variables. It focuses on people's opinions, beliefs, attitude and behaviour (Kerhinger, 1977; Agba 2007; Attah, 2010). Survey allows for the investigation of events to determine the nature and direction of the situation (Obasi, 1999). In other words, it permits for the objective, and rational description of existing events or phenomenon.

The population of study consists of medical and paramedical staff from primary, secondary and tertiary hospitals across the SSGPZN. A sample size of 1109 respondents was purposively selected for the study. The distribution cut across medical doctors and paramedical personnel. A four point likert scale questionnaire was administered to respondents. The questionnaire was divided into two sections. The first section (Section A) elicited socio-demographic data of respondents while (Section B) contained items that help in collecting information that aided the testing of the research hypotheses.

Elicited data were coded for various responses on the four point Likert scale questionnaire as shown in Table 2: Where

$\begin{array}{lll}\text { SA } & - & \text { Strongly Agree } \\ \text { A } & - & \text { Agree } \\ \text { D } & - & \text { Disagree } \\ \text { SD } & - & \text { Strongly Disagree }\end{array}$

Table 2: Coding of variables

\begin{tabular}{lcc}
\hline Response option & Positive & Negative \\
SA & 4 & 1 \\
A & 3 & 2 \\
D & 2 & 3 \\
SD & 1 & 4 \\
\hline
\end{tabular}

As depicted in Table 2, positive response to a positive question was ranked (4) for Strongly Agree (SA) while negative response to negative answer received the highest score of (4) for Strongly Disagree (SD). Other responses and scores follow the same sequence.

\section{Results}

Socio-demographic survey of respondents as depicted in Table 3 revealed that 83 percent $(n=921)$ were females while males were 17 percent $(n=188)$. The Table shows that majority of the respondents $(40.1 \%$, $\mathrm{n}=445)$ were between the ages of 31 and 40 years, followed by respondents who are below 30 years $(34.3 \%$; $\mathrm{n}=380)$. Those who are between 41 years and above were $(25.6 \% ; \mathrm{n}=284)$. Most of the respondents were married $(61.5 \% ; n=682)$ while singles were $(38.5 \% ; n=427)$.

Table 3 further reviewed that respondents with University degree were (68.3\%; $n=757)$, about nineteen percent $(19.2 \% ; n=213)$ were either OND or NCE holders; $(12.5 \% ; n=139)$ had other degrees including professional certificates, Masters of Science (MSc) and $\mathrm{PhD}$. Most respondents were senior staff (84.9\%; $\mathrm{n}=942)$; while $(15.1 \%$; $\mathrm{n}=167)$ were junior staff. The Table also shows that majority of the respondents $(64.2 \%$, 
$\mathrm{n}=712)$ were nurses, followed by medical doctors $(23.3 \% ; \mathrm{n}=258)$ and then laboratory technologists $(8.6 \%$; $\mathrm{n}=95)$ and radiographers $(4.0 \% ; \mathrm{n}=44)$ respectively.

Table 3: Socio-demographic Status of Respondents

\begin{tabular}{lll}
\hline Sex & Frequency & Percentage (\%) \\
Male & 188 & 17 \\
Female & 921 & 83 \\
Total & 1109 & 100 \\
Age & & \\
Below 30 & 380 & 34.3 \\
$31-40$ & 445 & 40.1 \\
41 and above & 1109 & 100.0 \\
Marital Status & & \\
Single & 427 & 38.5 \\
Married & 682 & 61.5 \\
Total & 1109 & 100.0 \\
Educational Status & 213 & \\
NCE/OND & 757 & 19.2 \\
University Degree & 139 & 68.3 \\
Others & 1109 & 12.5 \\
Total & & 100.0 \\
Category of Staff & 258 & \\
Medical Doctors & 712 & 23.3 \\
Nurse & 95 & 64.2 \\
Lab. Technology & 44 & 8.6 \\
Radiographer & 1109 & 4.0 \\
Total & & 100.0 \\
Rank & 167 & \\
Junior & 942 & 15.1 \\
Senior & 1109 & 84.9 \\
Total & & 100.0 \\
\hline
\end{tabular}

Source: fieldwork 2011

Ho: There is no significant relationship among wage differentials and industrial disputes. This hypothesis was tested using Pearson's product moment correlation statistic. The results are presented in Table 4.

Table 4: Pearson's correlation of the relationship among wage differentials and industrial disputes $(\mathrm{n}=1109)$.

\begin{tabular}{|c|c|c|c|}
\hline Variables & $\begin{array}{l}\bar{X} \\
\mathbf{X}\end{array}$ & SD & $\mathbf{r}$ \\
\hline Industrial disputes. & 10.65 & 2.14 & \\
\hline Wage differentials in terms of Basic Salary. & 10.69 & 2.32 & $-0.365^{*}$ \\
\hline Wage differentials in terms of fringe benefits allowance & 9.13 & 1.84 & $0.076^{*}$ \\
\hline Wage differentials in terms of hazard allowance & 10.17 & 2.17 & $0.182 *$ \\
\hline
\end{tabular}

* Significant at $.05, \mathrm{df}=1107$, critical $\mathrm{r}=0.062$

Results of analysis in Table 4 show that, the calculated $r$ - values for basic salary (-0.365), fringe benefit allowance (0.076) and hazard allowance (0.182) were each in absolute greater than the critical $r$ - value of 0.062 at .05 level of significance with 1107 degrees of freedom. These results imply that there is a significant relationship among wage differentials regarding the three variables and industrial disputes.

A further interpretation of the results confirms an inverse relationship between wage differentials in terms of basic salary and industrial disputes. That is, the more wages differ in terms of basic salary, the less industrial disputes occur among medical and para-medical staff of Nigerian hospitals. The results are different for fringe benefits and hazard allowances where the relationship was positive (direct). In these results, the more wages differ in terms of fringe benefits and hazard allowance, the more industrial disputes occur among medical and para-medical staff of hospital in Nigeria.

$\mathrm{Ho}_{2}$ : There is no significant predictive validity of socio-demographic factors of medical and para-medical staff on industrial disputes. Multiple regression analysis technique was employed in testing the hypothesis. The results are presented in Tables 5 and 6. 
Table 5: Summary of results for composite effect of socio-demographic factors on industrial disputes $\mathrm{R}=0.382 ; \mathrm{R}$ - square $=0.146 ;$ Std Error $=1.983$

\begin{tabular}{|c|c|c|c|c|c|}
\hline $\begin{array}{l}\text { Sources } \\
\text { Variation } \\
\end{array}$ & of & Df & MS & $\mathbf{F}$ & Sig \\
\hline Regression & 739.211 & 5 & 147.842 & $37.607 *$ & .000 \\
\hline Residual & 4336.132 & 1103 & 3.931 & & \\
\hline Total & 5075.344 & 1108 & & & \\
\hline
\end{tabular}

* Significant at .05

Predictors: (constant), category of staff, educational qualification, sex, marital status, age.

Table 6: Multiple regression of the relative effect of socio-demographic factors on industrial disputes

\begin{tabular}{llllll}
\hline Variables & B & SD & Beta & T & Sig \\
\hline Constant & 13.191 & 0.627 & & 21.025 & .000 \\
Sex & -0.574 & 0.164 & -0.101 & -3.511 & .000 \\
Age & -0601 & 0.085 & -0.216 & -7.115 & .000 \\
Marital Status & 0.416 & 0.133 & 0.095 & 3.119 & .000 \\
Educational Qualification & -0.654 & 0.100 & -0.187 & -6.556 & .000 \\
Category of Staff & 0.801 & 0.088 & 0.257 & 9.055 & .000 \\
\hline
\end{tabular}

Table 5 shows that a combination of five socio-demographic factors in predicting industrial disputes yielded a coefficient of multiple regression of 0.382 , a multiple R-square of 0.146 and a standard error of 1.983 . The major interpretation of this is that $14.6 \%$ of the variance in industrial disputes can be explained by the combined influence of the five socio-demographic factors. The Table also shows that the analysis of variance for the multiple regression data produced an F-ratio of $37.607^{*}$ which is significant at 0.05 levels. This indicates the effectiveness of the predictor variables (socio-demographic factors) in predicting industrial disputes; and that these crises could not have occurred by chance.

Table 6 shows Beta weights of $-0.101,-0.216,0.095,-0.187$ and 0.257 for sex, age, marital status, educational qualification and staff category respectively. The weights provide indication of relative effect of the predictor variables on the prediction of industrial disputes. The values of $t$ - ratio for all the variables are significant at 0.05 level with staff category $(\mathrm{t}=9.055)$ having the greatest influence, followed by age $(\mathrm{t}=7.115)$ and then educational qualification $(\mathrm{t}=6.556)$ and so on.

Ho $: \quad$ There is no significant predictive validity of the wage differential indicators on industrial disputes. Multiple regression analysis techniques was used in testing the hypothesis. The results are presented in tables 7 and 8 .

Table 7: Summary results for composite effect of wage differentials in terms of hazard allowance, basic salary and fringe benefit on industrial disputes.

\begin{tabular}{|c|c|c|c|c|c|}
\hline $\begin{array}{ll}\text { Sources } \\
\text { Variation }\end{array}$ & SS & df & MS & $\mathbf{F}$ & Sig. \\
\hline Regression & 831.386 & 3 & 277.129 & $72.156^{*}$ & .000 \\
\hline Residual & 4243.958 & 1105 & 3.841 & & \\
\hline Total & 5075.344 & 1105 & & & \\
\hline
\end{tabular}

* Significant at .05.Predictors: (constant), wage differentials in terms of hazard allowance, basic salary and fringe benefits.

Table 8: Multiple regression of the relative effective of wage differentials on industrial disputes

\begin{tabular}{llllll}
\hline Variables & B & SD & Beta & T & Sig \\
\hline Constant & 12.440 & 0.567 & & 21.932 & .000 \\
Basic salary & -0.333 & 0.026 & -0.361 & -12.677 & .000 \\
Fringe Benefit & 0.001 & 0.033 & 0.001 & .037 & .971 \\
Hazard allowance & 0.174 & 0.027 & 0.176 & 6.346 & .000 \\
\hline
\end{tabular}

Table 7 shows that a combination of three wage factors (hazard allowance, basic salary and fringe benefit allowance) in predicting industrial disputes yielded a coefficient multiple regression of 0.405 , a multiple R-square of 0.164 and a standard error of 1.960 . The major interpretation of this is that $16.4 \%$ of the variance in industrial disputes can be explained by the combined influence of hazard allowance, basic salary and fringe benefit allowance. The Table also revealed that the analysis of variance for the multiple regression data produced an F-ratio of $72.156^{*}$ which is significant at 0.05 levels. This indicates the effectiveness of the predictor variable (basic salary, hazard and fringe benefit allowance) in predicting industrial disputes and that these disputes could not have occurred by chance. 
Table 8 shows Beta weight of $-0.361,0.001$, and 0.176 for basic salary, fringe benefit and hazard allowance respectively. The weight provides an indication of relative effect of each of the predictor variable on the prediction of industrial disputes in hospitals in Nigeria. The values of t-ratio for all the variables are significant at 0.05 level with hazard allowance $(\mathrm{t}=6.346)$ having the greatest influence, followed by fringe benefit allowance $(\mathrm{t}=.037)$ and then basic salary.

\section{Discussion}

This study showed a positive direct relationship between wage differentials in terms of fringe benefit hazard allowance and industrial disputes in Nigerian hospitals. This suggests that the more the wage differs in terms of hazard and fringe benefits allowances among medical and para-medical staff, the more the incidence of industrial disputes in Nigerian hospitals. Agba, Ushie and Agba (2009) observe that the proportion and frequency of wage induced industrial disputes in Nigeria is alarming and unprecedented. Their views in line with the research findings suggest that wage differentials in terms of hazard and fringe benefit allowance is significantly responsible for the escalating rate of wage induced industrial disputes among medical and paramedical staff in Nigeria. Meaning the perceived increase in hazard and fringe benefits allowance of medical staff could triggers agitation among para-medical staff for similar increase and when their demands are not met, the possibility of embarking on strike becomes unavoidable.

Wage differential between hospital staff and political office holders could account for strike actions in Nigerian hospitals. The disproportionate increase in the wages of political office holders as against civil servants informed all types of industrial actions. Nigeria Labour Congress (2009) observed that between 2006 and 2007 political office holders received over 800 percent wage increase against 40 percent for public workers. The "starvation wages" given to civil servants (Cheeka, 2009) makes it increasingly difficult for the average Nigerian worker increasing difficult to survive on monthly remunerations. The workers situation is further aggravated in the face of increasing inflation of about 14 percent. The quest for better pay/wages by worker according to Agba (2007) result to industrial crisis and in most cases medical and Para-medical staff is involved.

Pearson correlation coefficient between basic salary and industrial disputes revealed an inverse relationship among the two variables, it shows that, the more wage differs in terms of basic salary, the less industrial disputes occur among medical and para-medical staff in Nigerian hospitals. This implies that the incidence of industrial disputes in Nigerian hospitals can be curtailed or reduced if basic salary differs or if wage policy makers manipulate the variable (basic salary) to ensure differentials among medical and para-medical staff. However Agba (2007) observe that differential in basic salary and other allowances among academic and non-academic staff in universities significantly affects the incidence of industrial disputes in Nigeria. He posits that when wages are increased in favour of academic staff, non-academic staff often embarks on strikes to press on government to increase their salaries.

The plight of the Nigerian worker in terms of poor remuneration as compared to other African countries could inform industrial disputes even when basic salary differs. In other words, the awareness among workers that they are negatively positioned in terms of wages as compared to their colleagues in other countries in Africa could raise agitation for better wages (basic salary and other allowances inclusive). Such awareness gathered momentum when Nigeria Labour Union in 2009 ex-rayed the wages of employees in other subSaharan African countries alongside that of workers in Nigeria and discovered that the Nigerian worker is the least paid in African, despite government huge earnings from crude oil. This revelation significantly influenced workers agitation for living wages between 2009 and 2011. Similarly, Fashoyin (1999) and Otobo (2000) have argued that the economic boom of the 1970s brought unprecedented increase in workers demand for enhanced wages; strategies such as strikes, work-to-rule, overtime ban and lock-out were frequently applied to press government and other employers of labour to meet their request.

The study also revealed that five socio-demographic factors of respondents predict the incidence of industrial disputes in Nigerian hospitals. It shows that 16.4 percent of variance in industrial disputes can be explained by the combined effect of socio-demographic factors such as age, sex, marital status, educational attainment and category of staff. The study further reveals that, category of staff ( $t=9.055)$ have the greatest influence on industrial disputes followed by age $(t=7.115)$ and the educational qualification $(t=6.556)$. This suggest that the propensity of nurses $(64.2 \%, \mathrm{n}=712)$ involvement in industrial actions is higher, followed by medical doctors $(23.3 \% ; \mathrm{n}=258)$. It also suggests that their unions are very coordinated to effectively mobilize its members for industrial actions such as strikes, work- to- rule etc. This could explain the relative high wages among this category of staff over others. It could also explain the influence of collective bargaining and organized labour in wage determination as argued by Killy (1967) and Owoye (2011).

The study reveals that 14.6 percent of industrial disputes in Nigerian hospitals are caused by combined influence of basic salary, hazard and fringe benefit allowance suggesting that there are other predicting factors of industrial disputes in Nigerian hospitals. The combined effect of wage differential (14.6\%) and sociodemographic factor $(16.4 \%)=$ sum $(30.0 \%)$ accounts for industrial disputes in Nigerian hospitals, meaning other 
variables or predictors accounts for $(70 \%)$ of industrial disputes in hospitals. It also shows that hazard allowance affects industrial disputes the most, followed by fringe benefit allowance and basic salary. Imhabekhai (2001) and Agba (2007) have argued that employers' refusal to implement collective agreement accounts for most industrial conflict in Nigeria. Fashoyin (1999) and Otobo (2000) posit that factors such as economic prosperity or recession influenced industrial crisis in Nigeria. Agba et al (2010) observed that government policies such as privatization, liberation and commercialization are often responsible for industrial disputes in Nigeria. This therefore suggests that, the 70\% predictive factors (of industrial dispute in Nigerian hospitals) not accounted for in this study could include employers' refusal to implementation agreement, economic prosperity or recession, government socio-economic policies among others. This suggests a further empirical research in these areas.

\section{Conclusion}

Wage induced industrial disputes are unprecedented in Nigeria and its negative impacts are numerous. Plethora of studies revealed the incidence of industrial disputes in other sectors of the Nigerian society with near absent of such empirical research in the health sector especially in hospitals. This study therefore examined the effect of wage differentials among medical and para-medical staff on industrial disputes in Nigerian hospitals. In doing so emphasis were laid on the impact of wage variables such as basic salaries, fringe benefit and hazard allowance on industrial disputes. The study showed interlink between wage differentials and industrial disputes in primary, secondary and tertiary hospitals in Nigeria. The study further revealed that socio-demographic variables such as age, sex, marital status, educational qualification and category of staff are some of the predictive factors in industrial disputes in Nigerian hospitals. This suggests that sex, age, category of staff, rank and marital status of respondents influenced their agitation for wage enhancement which often results to industrial disputes. Policy reform options were recommended to reduce the incidence of industrial crisis in Nigerian hospitals. Fair and enhanced wages should also be paid to medical and para-medical staff. The remunerations of medical practitioners should be at per with that of political office holders in Nigeria.

\section{References}

[1]. Agba, A. M. O., Ikoh, M. U., Ushie, E. M. \& Agba, M .S. (2008). Bureaucratic Corruption in Nigeria: The Need for Institutional Reforms. Journal of International Politics and Development Studies. 4 (1\&2), 187-204.

[2]. Agba, A. M. O. (2007). External Factors in Industrial Crisis. A study of Higher Institutions in Cross River and Akwa Ibom States, Nigeria. Unpublished Ph.D Thesis of the University of Calabar, Calabar, Nigeria.

[3]. Agba, A. M. O. \& Agba, M. S. (2008). Socio-economic and Political Implications of industrial Crisis in Nigerian Higher Institutions of Learning. Journal of Policy and Development Studies, 11 (2), 44-48.

[4]. Agba, A. M. O., Ushie, E. M. \& Agba, M. S. (2009). External factors in Industrial Crisis in Nigeria Civil Service. Nigerian Journal of Labour Law and Industrial Relations, 3(3), 75-94.

[5]. Agba, A. M. O., Ikoh, M. Ushie, E. M. \& Bassey, A. O. (2010). Telecommunications Revolution: Implications on Criminality and Family Crisis in the South-South States of Nigeria. International Journal of Computer and Information Science, 3 (1), $42-51$.

[6]. Agba, A. M. O., \& Ushie, E. M. (2010). Motivational Incentives and Staff Turnover in the Hospitality Industry in Cross River State, Nigeria. Global Journal of Management and Business Research, 10 (8), 18-28.

[7]. Agba, A. M. O., Ushie, E. M., Agba, M. S. \& Nkpoyen, F. (2010). Privatization, Job Security and Performance Efficiency of Privatized Enterprises in Nigeria. Researchers World- Journal of Arts Science and Commerce, 1(1), 95-102.

[8]. ASUU National Executive Council (2005). ASUU's Response to the Federal Ministry of Education Press Release/Advertorial. Daily Sun, 38-39

[9]. Attah, F. M. (2010). Calabar Carnival Festal and Socio-Economic Development of Cross River State, Nigeria $2000-2008$. Unpublished PhD Thesis of the University of Calabar, Calabar, Nigeria.

[10]. Bassey, C. O. (2002). Political Parties and Conflict Resolution in Nigeria: Towards an Analysis of Basic Trend and Pattern in the South-South Zone. Nigerian Journal of Social and Development Issues, 2 (20), 79-96.

[11]. Beck, C. E. (1999). Managerial Communication: Bridging Theory and Practices. New Jersey: Prentice Hall

[12]. Cheeka, D. (2009). Nigeria: Living Wage a Must. Online available at: http;//www.marxist.com/nigeria-living-wage-amust.html.retrieved22/3/11

[13]. Deutsel, M. (1973). The Resolution of conflict Constructive and Destructive Processes. New Haven: Yale University Press.

[14]. Dipboye, R. L., Smith, C. S. \& Howell, W. C. (1994). Understanding Industrial Organizational Psychology. An Integrated Approach (PP.190-195). New York; Harcourt Brace College Publishers.

[15]. Dubrin, A. J. (1992). Human Relations: A Job Oriented Approach. New Jersey: Prentice Hall.

[16]. Fashoyin, T. (1999). Industrial Relations in Nigeria ( $2^{\text {nd }}$ Ed). Ikeja; Longman.

[17]. Groshen, E. L. (1991). Five Reasons Why Wages Vary Among Employers. Industrial Relations, Fall, PP.350-381.

[18]. http://www.economiesconcepts.com(2011). Theories of Wages determination. Available http://www.economiesconcepts.com/marginal-productivity-thoery-of-wages-under-perfec..7/24/2011.

[19]. Hutt, W. H. (1954). The Theory of Collective Bargaining. U.S.A: The Free Press.

[20]. Imhabekhai, C. I. (2001). Conflict in higher educational management. In N. A. Nwangwu, E. T. eliametelor, M. A. Nwandiani (Eds). Current issues in educational management in Nigeria. (PP.103-113). Benin City: Ambik Press,

[21]. Kabubo-Mariara, J. (2003). "Wage Determination and the Gender Wage Gap in Kenya: Any Evidence of Gender Discrimination?" African Economic Research Consortium Research Paper 132. Nairobi AERC.

[22]. Kerhinger, R. A. (1977). Foundations of Behaviour Research. New York: Halt Rienehart and Winston.

[23]. Kelly, J. (1998). Rethinking Industrial Relations: Mobilization Collectivism and Long Waves. London: Routledge.

[24]. Killy, P. (1967). Industrial Relations and Wage Determination: Failure of the Anglo-Saxon Model. The Journal of Developing Area Vol.1, No 4

[25]. Knight, J. B. \& Sabot, R. H. (1990). Education Productivity and Inequality: The East African Natural Experiment. New York: Oxford University Press 
[26]. Mamoria, C. B., Mamoria, S. \& Gankar, S. V. (2009). Dynamic of Industrial Relations (9 $9^{\text {th }}$ Ed). Mumbai: Himalaya Publishing House.

[27]. March, J. \& Simon, H. (1993). Organizations. Cambridge: Blackwell.

[28]. Navamukundan, A.(2011). Wage determination and grievance procedures in the private sector in Malaysia, Sri Lanka and South Korea. Online available at http://www.gurn.info/en/topics/Wages\%20and\%20Collective\%20B argaining/international-andgeneral/wage-determination-and-grievance-procedures-in- the-private-sector-in-malysia-sri-lanka-and-south-korea-anavamukundan/view

[29]. Neumark, D. \& wascher, W. (2006). Minimum wages and employment: a review of evidence from the new minimum wage research. Working paper 12663: Online available at; http://www.nber.org/papers/w12663. Retrieved 25/7/11.

[30]. Nigeria Labour Congress (2009). "Nigeria Labour Congress Demand for the Review of the National Minimum and General Wage Review'. On line available at http://www.nicng.org/minimum\%20wage.pdfretrieved22/3/11.

[31]. Obasi, I. (1999). Research Methodology in Political Science. Enugu: Academic Publishing Company.

[32]. Oshiomole, A. (2009) "Mainstreaming Mediation in Labour Disputes Resolution." Paper presented at the $1^{\text {st }}$ National Summit on Labour Disputes Resolution held in Abuja on the $4^{\text {th }}$ and $5^{\text {th }}$ December 2009 at the National Universities Commission and the National Merit House and Organized by the Ministry of Labour and Productivity

[33]. Otobo, D. (1982). Collective Bargaining: Myth and Reality. The Nigerian Journal of Economic and Social Studies, 26, PP. 247-270.

[34]. Otobo, D. (2000). Industrial Relations: Theory and Controversies. Lagos: Malthouse Press.

[35]. Owoye, O. (2011). Wage Determination and Strike Activity in Nigeria. Journal of African Economies, 3 (3), $447-480$.

[36]. Phillips, R. C. (1988). Manage Difference before they Destroy your Business. Training and Development Journal, 42 (9), 66-71.

[37]. Ratnam, C. S. V. (2007). Industrial Relations. New Delhi: Oxford University Press.

[38]. Rollinson, D. \& Dundon, T. (2007). Understanding Employment Relations. London: McGraw Hill Higher Education.

[39]. Tjosvold, D. (1986). Working Together to Get Things Done. In R. L. Dipboye, C. S. Smith and W. C. Howell (Eds). Understanding Industrial Organizational Psychology. An Integrated Approach (PP.190-195). New York; Harcourt Brace College Publishers.

[40]. Tutor $\mathrm{u}$ (2011). Wage Determination in Competitive Markets. Online available at http://tutor2u.net/economics/revicion-notes/a2micro-wage-determinate.retrieved22/3/11

[41]. Ugal, G. A. (2008). Industrial Psychology. Calabar: Jamel Technical.

[42]. Us Department of Labour (2011). General Wage Determinations Issued Under the Davis-Bacon and Related Acts. Online available at: http://www.gpo.gov/davisbacon/referencemat:html.retrived22/3/2011

[43]. Ushie, E. M. \& Iyam, U. I (2004). Introduction to Labour and Industrial Relations in Nigeria. Calabar: Unique Link.

[44]. Wikipedia, $\left(2011^{\mathrm{a}}\right)$. Salary. Online available at: http://en.wikipedia.org/wiki/salary. Retrieved 15/6/11.

[45]. Wikipedia, $\left(2011^{\mathrm{b}}\right.$ ). Wages and Salaries. Online available at: http://en.wikipedia.org/wiki/wages-and-salaries. Retrieved 15/6/11.

[46]. Yesufu, T. M. (1962). Introduction to Industrial Relations in Nigeria. London: Oxford University Press. 